\title{
ПРАВОВОЙ СТАТУС ПРОИЗВОДНЫХ ФИНАНСОВЫХ ИНСТРУМЕНТОВ В РОССИЙСКОЙ ФЕДЕРАЦИИ
}

\section{LEGAL STATUS OF DERIVATIVES IN THE RUSSIAN FEDERATION}

\section{E. Tokarev}

Summary: The article considers the issue of defining the concept of «derivative financial instrument» both from the point of view of private law branches and from the position of public law, and also suggests the possibility of using varieties of this financial instrument not only to ensure the turnover of private capital, but also for the purpose of obtaining public income.

Keywords: derivative financial instrument, derivative, underlying asset, contract, term transaction, exchange, public income, public expenses.

\author{
Токарев Эдуард Андреевич \\ Аспирант, Российский государственный \\ университет правосудия \\ tok.edward@yahoo.com
}

Аннотация: В статье рассматривается вопрос определения понятия «производный финансовый инструмент» как с точки зрения отраслей частного права, так и с позиции публичного права, а также высказывается предложение о возможности использования разновидностей указанного финансового инструмента не только для обеспечения оборота частного капитала, но и в целях получения публичных доходов.

Ключевые слова: производный финансовый инструмент, дериватив, базисный актив, договор, срочная сделка, биржа, публичные доходы, публичные расходы.
B соответствии с действующим законодательством Российской Федерации деривативы представляют собой производные финансовые инструменты, направленные на развитие рыночных отношений, хеджирование рисков при заключении торговых сделок, и предполагающие правоотношения по реализации приобретенных прав и обязанностей в определенный период времени.

Однако правовое регулирование производных финансовых инструментов не развито с точки зрения законодательства о деривативах. Определение особенностей их обращения передано Банку России; сделки с деривативами, обращающимися на организованных торгах, подчинены правилам биржи'. Основываясь на последнем факте, правовое регулирование деривативов можно разделить на относящееся к обращающимся и необращающимся на организованных торгах производным финансовым инструментам.

Согласно статье 2 Федерального закона «О рынке ценных бумаг» [9], производный финансовый инструмент - договор, за исключением договора репо, предусматривающий одну или несколько из следующих обязанностей:

1. обязанность сторон или стороны договора периодически или единовременно уплачивать денежные суммы, в том числе в случае предъявления требований другой стороной, в зависимости от изменения цен на товары, ценные бумаги, курса соответствующей валюты, величины процентных ставок, уровня инфляции, значений, рассчитываемых на основании цен производных финансовых инструментов, значений показателей, составляющих официальную статистическую информацию, значений физических, биологических и (или) химических показателей состояния окружающей среды, от наступления обстоятельства, свидетельствующего о неисполнении или ненадлежащем исполнении одним или несколькими юридическими лицами, государствами или муниципальными образованиями своих обязанностей (за исключением договора поручительства и договора страхования), либо иного обстоятельства, которое предусмотрено федеральным законом или нормативными актами Центрального банка Российской Федерации (далее - Банк России) и относительно которого неизвестно, наступит оно или не наступит, а также от изменения значений, рассчитываемых на основании одного или совокупности нескольких указанных в настоящем пункте показателей. При этом такой договор может также предусматривать обязанность сторон или стороны договора передать другой стороне ценные бумаги, товар или валюту либо обязанность заключить договор, являющийся производным

В соответствии с частью 11 статьи 4 Федерального закона от 21.11.2011 № 325-Ф3 «О6 организованных торгах» организаторы торговли, осуществляющие проведение организованных торгов, на которых заключаются договоры, являющиеся производными финансовыми инструментами, обязаны утвердить спецификации таких договоров, соответствующие требованиям нормативных актов Банка России. Указанные спецификации договоров, а также вносимые в них изменения должны быть зарегистрированы в Банке России. 
финансовым инструментом;

2. обязанность сторон или стороны на условиях, определенных при заключении договора, в случае предъявления требования другой стороной купить или продать ценные бумаги, валюту или товар либо заключить договор, являющийся производным финансовым инструментом;

3. обязанность одной стороны передать ценные бумаги, валюту или товар в собственность другой стороне не ранее третьего дня после дня заключения договора, обязанность другой стороны принять и оплатить указанное имущество и указание на то, что такой договор является производным финансовым инструментом.

Как указывает М.Н. Греков, в мировой практике под деривативом понимают финансовые инструменты, ценность которых проистекает из колебания цен на соответствующие активы, такие, как финансовые продукты или статистические индикаторы. Из содержания определения производных финансовых инструментов видно, что оно включает в себя все то многообразие совершаемых на биржевых и внебиржевых торгах сделок с отсроченным сроком исполнения, которые в мировой практике могут обозначаться как деривативы, биржевые срочные сделки и т.д. [2]

Однако производный финансовый инструмент выходит за рамки гражданско-правового договора, определенного в Гражданском кодексе Российской Федерации (далее - ГК РФ) [11], т.к. в соответствии со статьей 420 ГК РФ договором признается соглашение двух или нескольких лиц об установлении, изменении или прекращении гражданских прав и обязанностей. Гражданские права и обязанности возникают в отношении объектов гражданских прав ${ }^{2}$ В свою очередь, перечень объектов гражданских прав приведен в статье 128 ГК РФ (вещи, иное имущество, результаты работ и оказание услуг, ох- раняемые результаты интеллектуальной деятельности и приравненные к ним средства индивидуализации, нематериальные блага).

При этом, базисным активом производных финансовых инструментов - объектом, в отношении которого заключаются деривативы [4] - согласно статье 301 Налогового кодекса Российской Федерации (далее - НК РФ) [8] являются в том числе процентные ставки, кредитные ресурсы, индексы цен или процентных ставок, другие производные финансовые инструменты.

В Указании Банка России «О видах производных финансовых инструментах» [14] базисный актив раскрыт еще большим перечнем объектов, отдельные виды которых не являются с точки зрения ГК РФ объектами гражданских прав ${ }^{3}$.

НК РФ закрепляет ограничение, согласно которому не признается производным финансовым инструментом договор, требования по которому не подлежат судебной защите в соответствии с гражданским законодательством Российской Федерации и (или) применимым законодательством иностранных государств.

В соответствии с пунктом 1 статьи 1062 ГК РФ [10] на требования, связанные с участием в сделках, предусматривающих обязанность стороны или сторон сделки уплачивать денежные суммы в зависимости от изменения цен на товары, ценные бумаги, курса соответствующей валюты, величины процентных ставок, уровня инфляции или от значений, рассчитываемых на основании совокупности указанных показателей, либо от наступления иного обстоятельства, которое предусмотрено законом и относительно которого неизвестно, наступит оно или не наступит, правила настоящей главы не распространяются. Указанные требования подлежат судебной защите, если хотя бы одной из сторон сдел-

2 Объекты гражданских прав - это объективированные материальные и нематериальные блага, в отношении (по поводу) которых возникают гражданские права и обязанности, складываются и действуют гражданские правоотношения. // Алексеев С.С. Комментарий к Гражданскому кодексу Российской Федерации (учебно-практический). Части первая, вторая, третья, четвертая (постатейный) / С.С. Алексеев, А.С. Васильев, В.В. Голофаев и др.; под ред. С.А. Степанова. 2-е изд., перераб. и доп. М.: Проспект; Екатеринбург: Институт частного права, 2009. 1504 с.

3 Базисными активами производных финансовых инструментов являются ценные бумаги, товары, валюта, процентные ставки, уровень инфляции, официальная статистическая информация, физические, биологические и (или) химические показатели состояния окружающей среды, договоры, являющиеся производными финансовыми инструментами, значения, рассчитываемые на основании одного или совокупности нескольких указанных в настоящем пункте показателей, от цен (значений) которых зависят обязательства стороны или сторон договора, являющегося производным финансовым инструментом.

Базисным активом производного финансового инструмента также является наступление обстоятельства, соответствующего условиям, предусмотренным договором, являющимся производным финансовым инструментом, и свидетельствующего о неисполнении или ненадлежащем исполнении одним или несколькими юридическими лицами, государствами или муниципальными образованиями (далее - контрольное лицо) своих обязанностей, о наличии оснований для предъявления требования о досрочном исполнении обязанностей контрольного лица, о реструктуризации задолженности контрольного лица, о признании контрольного лица несостоятельным (банкротом), о действиях государственных органов, способных воспрепятствовать исполнению контрольным лицом своих обязанностей, либо иного обстоятельства, которое предусмотрено законодательством Российской Федерации и относительно которого неизвестно, наступит оно или не наступит (далее - кредитное событие), при условии, что о наступлении такого кредитного события сделано сообщение, соответствующее условиям, предусмотренным договором, являющимся производным финансовым инструментом. 
ки является юридическое лицо, получившее лицензию на осуществление банковских операций или лицензию на осуществление профессиональной деятельности на рынке ценных бумаг, либо хотя бы одной из сторон сделки, заключенной на бирже, является юридическое лицо, получившее лицензию, на основании которой возможно заключение сделок на бирже, а также в иных случаях, предусмотренных законом. Требования, связанные с участием граждан в указанных в настоящем пункте сделках, подлежат судебной защите только при условии их заключения на бирже, а также в иных случаях, предусмотренных законом.

Соответственно, для осуществления сделок с базисным активом, который не является объектом гражданских прав, необходимо, чтобы стороной сделки являлась организация, у которой имеется соответствующая лицензия, а также чтобы сделка заключалась на организованных торгах. В отсутствие указанных условий подобные операции не подлежат судебной защите и признаются в качестве пари (статья 1062 ГК РФ).

Как указывает Е.В. Иванова, деривативный договор представляет собой непоименованный предпринимательский договор sui generis, заключаемый с целью получения прибыли или хеджирования предпринимательских рисков, цена которого зависит от размера цены базового актива на реальном рынке. Неопределенность получения встречного предоставления позволяет классифицировать деривативный договор в качестве особой разновидности алеаторных договоров, отличных от игр и пари [5].

Подобные проблемы с квалификацией деривативного договора также возникают ввиду неопределенности понятия «срочная сделка» в соответствии со статьей 301 НК РФ.

По справедливому замечанию Л.Г. Кузнецова, неурегулированность юридического статуса срочных сделок является одной из главных проблем отечественного срочного рынка, в процессе совершенствования законодательной базы этого рынка не следует ограничиваться внесением поправок в ст. 1062 ГК РФ. Необходимо внести и дополнение к главе 9 «Сделки», определив в ней понятие «срочная сделка» [6].

Согласно статье 44 Федерального закона «О рынке ценных бумаг» [9], квалификация производных ценных бумаг, определение их видов - право Банка России.

Так в Указании Банка России «О видах производных финансовых инструментах» обозначены следующие виды деривативов:

- опционный договор;

\section{- фьючерсный договор; \\ - форвардный договор; \\ - своп-договор.}

Данный факт позволяет определить, что оборот производных финансовых инструментов включен в деятельность Банка России по банковскому регулированию и банковскому надзору (статья 56 Федерального закона «О Центральном банке Российской Федерации (Банке России)» [12]).

Необходимо отметить, что императивное установление Федеральным законом, актами Банка России закрытых перечней видов деривативов, базисных активов не позволяет получить должную правовую защиту при использовании производных финансовых инструментов в отношении объектов, не включенных в указанные перечни, в том числе с учетом развития цифровой экономики (появления криптовалюты и т.п.).

По справедливому замечанию Т.Ю. Сафонова, оно [определение производного финансового инструмента], с одной стороны, достаточно полно охватывает весь спектр возможных производных финансовых инструментов и позволяет признавать таковыми отдельные финансовые операции, но, с другой стороны, основывается на наличии в договорах определенной совокупности требований и обязательств сторон договора. В сложившейся ситуации незначительное изменение состава таких требований и обязательств позволяет контрагентам не признавать сделку в качестве ПФИ, хотя по экономической сути она таковой является [7].

Стоит заметить, что, не смотря на особенности определения базисных активов, закрепления видов и признаков деривативов, законодательство, регулирующее оборот производных финансовых инструментов, не ограничивает возможность их применения в предпринимательской и иной экономической деятельности.

Указанное позволяет сделать вывод о том, что несмотря на особенности правового регулирования элементов правоотношений по обороту производных финансовых инструментов, использование деривативов допустимо не только в деятельности по обороту частного капитала, но и в деятельности, связанной с формированием публичных доходов и использованием публичных расходов.

Ведь, как отмечают исследователи в области финансового права, публичность приобретает новые формы, а методы государственного регулирования не заменяются частными, а скорее интегрируются и систематизируются в совершенно новые формы воздействия [1]. 


\section{ЛИТЕРАТУРА}

1. Imeda A Tsindeliani, Svetlana V Miroschnik, Inessa V Bit-Shabo, Anatoly D Selyukov, Maxim M Proshunin, Svetlana V Rybakova, Ekaterina G Kostikova, Svetlana S Tropskaya. Financial law as a public law branch: A fresh look at the signs of publicity // Journal of Legal, Ethical and Regulatory Issues Volume 22, Issue 5, 2019

2. Греков М.Н. Проблемы правовой квалификации деривативного обязательства // Актуальные проблемы российского права. 2014. № 6. С. 1157 - 1166.

3. Алексеев С.С. Комментарий к Гражданскому кодексу Российской Федерации (учебно-практический). Части первая, вторая, третья, четвертая (постатейный) / С.С. Алексеев, А.С. Васильев, В.В. Голофаев и др.; под ред. С.А. Степанова. 2-е изд., перераб. и доп. М.: Проспект; Екатеринбург: Институт частного права, 2009. 1504 с.

4. Почежерцева 3.А., Холкина М.Г., Шевченко Г.Н. Комментарий к Федеральному закону от 22 апреля 1996 г. № 39-Ф3 «0 рынке ценных бумаг» (постатейный) // СПС КонсультантПлюс. 2014.

5. Иванова Е.В. Договорные формы деривативов: некоторые аспекты правового регулирования // Закон. 2007. № 2. С. 125 - 135.

6. Кузнецова Л.Г. Российский рынок производных инструментов: вопросы правового регулирования // Законодательство и экономика, 2006 , № 8.

7. Сафонова Т.Ю., Терехович Ю.В. Проблемы создания системы регулирования рынка ПФИ // Банковское право. 2014. № 5. С. 15 - 23.

8. Налоговый кодекс Российской Федерации (часть вторая) от 05.08.2000 № 117-Ф3 // Собрание законодательства Российской Федерации, 07.08.2000, № 32, ст. 3340.

9. Федеральный закон от 22.04.1996 № 39-Ф3 «0 рынке ценных бумаг» // Собрание законодательства Российской Федерации, № 17, 22.04 .1996 , ст. 1918.

10. Гражданский кодекс Российской Федерации (часть вторая) от 26.01.1996 № 14-Ф3 // Собрание законодательства Российской Федерации, 29.01.1996, № 5, ст. 410.

11. Гражданский кодекс Российской Федерации (часть первая) от 30.11.1994 № 51-Ф3 // Собрание законодательства Российской Федерации, 05.12.1994, № 32, ст. 3301.

12. Федеральный закон от 10.07.2002 № 86-Ф3 «0 Центральном банке Российской Федерации (Банке России)» // Собрание законодательства Российской Федерации, 15.07.2002, № 28, ст. 2790.

13. Федеральный закон от 21.11.2011 № 325-Ф3 «06 организованных торгах» // Парламентская газета, № 51, 25.11.2011;

14. Указание Банка России от 16.02.2015 № 3565-У «0 видах производных финансовых инструментов» // Вестник Банка России, № 28, 31.03.2015.

(c) Токарев Эдуард Андреевич (tok.edward@yahoo.com).

Журнал «Современная наука: актуальные проблемы теории и практики»

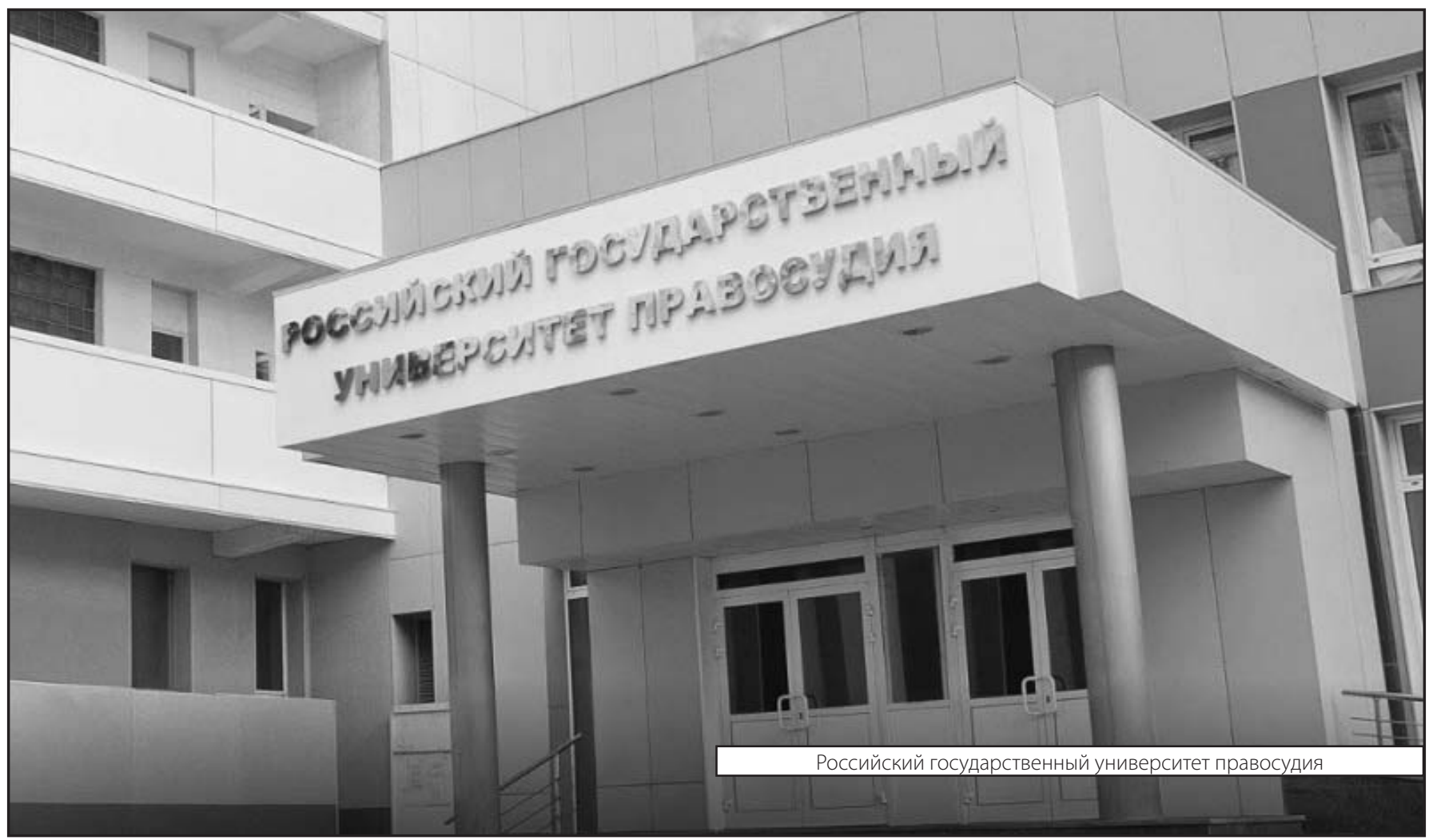

